\title{
Robert Holcot, O.P., on Prophecy, the Contingency of Revelation, and the Freedom of God
}

\author{
JOSEPH M. INCANDELA
}

In a recent work, William Courtenay refers to the issues in Holcot's writings under discussion in this essay as "theological sophismata." That they are. But it is the burden of this essay to suggest that they are more: Holcot's interest in these questions had a fundamentally practical import, and such seemingly esoteric philosophical and theological speculation was in the service of a pastoral program geared to preaching the faith to unbelievers. For someone in a religious order charged with this mission, questions that may initially appear only as sophismata may actually perform quite different functions when examined in context.

Robert Holcot was best known in his own time as a commentator on the Book of Wisdom. Wey writes that this work "made its author famous overnight and his fame held throughout the next two centuries." 2 Wey also proposes that it was because of the reputation won with the Wisdom-commentary that Holcot's Sentencescommentary and some quodlibet questions were printed four times

1. William J. Courtenay, Schools and Scholars in Fourteenth Century England (Princeton: Princeton University Press, 1987), p. 303.

2. Joseph C. Wey, "The Sermo Finalis of Robert Holcot," Medieval Studies 11 (1949): 219-224, at p. 219. 
between 1497 and 1518. His thought was also deemed important enough to be discussed and compared with that of Scotus and Ockham in a work by Jacques Almain printed in 1526. But sometime after this Holcot seems to have been relegated to the margins of the story of medieval thought. In 1958, Muckle spoke of what he thought an "increasing interest in Holcot."3 But by 1962 it seems that Johannes Beumer was still right to affirm that "strikingly little has been done on Holcot." 4 Though many hopeful signs have appeared in the thirtytwo years since that remark, ${ }^{5}$ there remains a dearth of writings on Holcot in English-a shame, since he is one the English ought to be proud to claim as their own. 6

Perhaps earlier characterizations of Holcot's work as "l'occamisme renforcé"7 have adversely affected the scholarly attention devoted to it (attention would naturally be drawn to the more original of the pair). Furthermore, in a rather famous (though now somewhat dated) essay of fifty years ago, Konstanty Michalski wrote that Holcot is nearest to Ockham of all the English nominalists by the fact that at every instant the former sought to disengage the verities of faith from philosophical

3. J. T. Muckle, “'Utrum Theologia Sit Scientia': A Quodlibet Question of Robert Holcot O.P.," Medieval Studies 20 (1958): 127-153, at p. 127.

4. Johannes Beumer, "Zwang und Freiheit in der Glaubenszustimmung nach Robert Holkot," Scholastik 37 (1962): 514-529, at p. 514.

5. There is a valuable review of the recent literature in Hester Gelber, Exploring the Boundaries of Reason: Three Questions on the Nature of God by Robert Holcot, O.P., Studies and Texts 62 (Toronto: PIMS, 1983), pp. 1-28. See also the very helpful introduction in the forthcoming volume of some of Holcot's quodlibets edited by Paul Streveler and Katherine Tachau.

6. In addition to his many and varied writings, there seems to be much about Holcot's life that makes him an extremely interesting-perhaps even edifying-figure on the medieval stage. According to Beryl Smalley, "No medieval moralist, and it is a large claim, ever had a stronger sense of humour." See her "Robert Holcot O.P.," Archivum Fratrum Praedicatorum 26 (1956): 5-97, at p. 5. After Holcot, writes Smalley, "The future of theology in England lay with grimmer, narrower men" (p. 97). Finally, Holcot died in the Black Death while serving others. The DTC reports, "Holcot mourut à Northampton, en 1329, victime de sa charité, en soignant les pestiférés, au cours du fléau qui, à cette époque, ravagea l'Angleterre" (7.1:30).

7. A. B. Emden explains that many of Holcot's positions have been described in this way. See his A Biographical Register of the University of Oxford to A.D. 1500 (Oxford: Clarendon Press, 1958), 2: 946. Emden adds that Holcot himself never felt that his views became incompatible with Thomism. 
argumentation. ${ }^{8}$ While there are several striking similarities between Ockham and Holcot, many contemporary scholars retreat from such strong claims of similarity. ${ }^{9}$ Coming out from Ockham's shadow may account for Holcot's increasing popularity among this generation of scholars. Certainly, there was and is much that commends Holcot as a fascinating figure in his own right. Though Holcot surely breathed the air of the fourteenth century, the winds of Thomism were still very much at his back-more so than for many other notable fourteenthcentury figures, because he was himself a member of the Order of Preachers. As such, Holcot's audience, Holcot's purposes in writing, Holcot's theology may be more distinctive than has traditionally been acknowledged. Looking at these questions in this way may also more clearly circumscribe the relation Holcot saw between faith and philosophy and thereby reveal him in a clearer and more distinct light.

In the first part of my remarks, I shall try to lay out how Holcot addressed the issues of prophecy, the contingency of revelation, and the freedom of God. I will also try to show what he considered at stake in their relationship. Both the freedom of the divine will and the freedom of the human will seem alternately imperiled depending on the sense one makes of prophecy and the contingency of revelation. (Obviously, Holcot was far from alone among his contemporaries in fourteenth-century Oxford in being concerned with such matters.) ${ }^{10}$ The second part of the essay will be briefer and more speculative.

8. Konstanty Michalski, "Le problème de la volonté à Oxford et à Paris au XIV siècle," Studia Philosophica: Commentarii Societatis Philosophicae Polonorum 2 (1937): 233-365, at p. 303.

9. For example, Courtenay states that "the parallels between Ockham and Holcot are too few to allow us to apply the label 'Ockhamist' to Holcot" (Schools and Scholars, p. 217). It is the case, of course, that Holcot's views on prophecy and God's revelation of future contingents bear many similarities to those advanced by William Ockham. For an account of the latter's positions, see Calvin Normore and Aron Edidin, "Oackham [sic] on Prophecy," International Journal for the Philosophy of Religion 13 (1982): 179-189. See also Normore, "Future Contingencies," in CHLMP, pp. $358-382$.

10. A concern with prophecy and God's intentions for the future was understandable in a century ravaged by the Hundred Years' War, the Babylonian Captivity of the papacy, and the Black Plague. Thus Holcot frequently laments with some justice "these modern times." On this complaint, see Heiko Oberman, Forerunners of the Reformation (Philadelphia: Fortress Press, 1966), p. 133. 
Holcot's literary corpus is made up of at least two kinds of writings: those in the usual academic genres (Sentences-commentary, quodlibetal questions, and so on) and some rather decidedly pastoral treatises dedicated to the training of preachers and the cultivation of piety. I conclude by offering an hypothesis about how to fit these two genres together. I want to suggest that the 'philosophical' Holcot of the Sentences-commentary and quodlibets and the more pious Holcot of the Wisdom-commentary and pastorally oriented moral writings are quite complementary. Indeed, they are so complementary that to attempt to focus on either apart from the other or to try to separate philosophical from theological agendas results, I think, in an incomplete picture of him.

\section{THE CONTINGENCY OF PROPHECY AND REVELATION}

At one point in his Sentences-commentary, Holcot gives the following definition of prophecy and states the implication it carries:

prophecy is divine inspiration announcing the outcomes of things with immutable truth. Therefore, if something is prophesied to happen in the future, it will immutably be in the future, and moreover: it will necessarily happen in the future. ${ }^{11}$

Suppose that revelation were only contingent, however. According to Holcot, it would seem that if events revealed by prophets were not necessarily true-that is, if it were possible for them not to happen at some future time-then it would be neither obligatory nor appropriate to believe prophecy. Neither would the prophecy of the above definition even be possible. If such revelation were contingent,

11. "[P]rophetia est divina inspiratio rerum eventus immobili veritate denuntians. Ergo, si aliquid est prophetatum esse futurum, illud immobiliter erit futurum, et ultra: necessario erit futurum." I would like thank Paul Streveler, West Chester University, for his generosity in making available to me much of what he and his colleagues will publish in the critical edition of portions of Holcot's Sentences-commentary and quodlibets. In references to Holcot's In quatuor libros sententiarum quaestiones, I shall cite the page number of the typescript of this edition. This description of prophecy is found there on pp. 8-9 (2.2). All translations from the Latin are my own. 
no one would be obliged to believe the prophets because the opposite of their promises could be true. It would follow, Holcot concludes, that the Jews were not obligated to believe the prophecies of Christ. In addition, consider Jesus' statement to Peter that Peter would thrice deny him. If Christ's statement were only contingently true, it seems that it was within the power of Peter to bring it about that Christ had asserted a false thing. If this were true, then Holcot says it was also in the power of the people with Peter at the time, because they could have killed him any time after Christ's prediction and before Peter's third denial.

The ramifications of the contingency of revelation become much more weighty when we consider things concerning future blessedness or fulfillment pledged and sworn to by God through Christ-say, the general resurrection of the dead. It would seem that God could certify nothing conclusively of any future occurrence inasmuch as it would always be contingently future. In short, if the revealed promises in Holy Writ were extended only contingently, they must then be dependent on future happenings. They could then be false, inasmuch as something contingent can not be. But if Scripture can be false, then those who think belief in the words of Scripture efficacious for salvation might be able to merit through false faith. And if God is able to reveal future contingents that remain contingent after their revelation, then-Holcot's example-a Sadducee who has presumably been justly damned for a thousand years for not believing the promises of Scripture is now able never to have been justly damned if those promises turn out to be false. Hence it is possible that this man never believed incorrectly and so was damned without cause.

Significant christological issues also arise here. Holcot readily admits that if Christ said there would be a resurrection and there isn't one (which would be possible given the contingency of the event prophesied), it is impossible to deny that the saying of Christ was false. ${ }^{12}$ Therefore, Christ said a false thing either knowingly or

12. Holcot, Quodlibet 3 8, line 472: "igitur impossible est vitare quin dictum Christi fuit falsum." This quodlibet, entitled "Utrum generalis resurrectio necessario sit futura," will be cited hereafter by line number with the abbreviated title Utrum generalis resurrectio. For a list of Holcot's quodlibets, see Palémon Glorieux, La littérature quodlibétique (Paris: J. Vrin, 1936), 2:258-261. For textual issues relating to the extant manuscripts of Holcot's quodlibets, see Gelber, Boundaries of Reason. 
ignorantly. If knowingly, Christ lied. If ignorantly, he was deceived.13 Neither alternative seemed to Holcot particularly palatable.

Holcot cites numerous authorities against Christ being made unfaithful to his promises: (1) 2 Timothy 2:13 reads, "He remains faithful; he is not able to deny himself." The gloss Holcot appeals to elaborates, "He who is truth "is not able to deny himself, which he would do if he did not fulfill his words." (2) If Christ were able to have been deceived or to have deceived others, it would follow, according to St. Augustine, ${ }^{14}$ that Christ is not the truth. (3) In Luke 24:44, Christ states that it is necessary that all things about him be fulfilled. (4) Finally, the gloss on Matthew 28:6 ("he rose just as he said") reads, "thus it is impossible that what he said not be done."15 If Christ prophesied a future resurrection, it is necessary that it be fulfilled. Consequently, revelation must not remain contingent after it is given.

Suppose then that revelation and prophecy were necessary. Holcot finds at least two difficulties with the supposition. First, God's freedom and power would be very much restricted if God were not now able to falsify propositions God has revealed in the past. Second, if revelation does not remain contingent, then human free will would be taken away regarding those things prophesied of future human actions. Note that the issue of prophecy is even more insidious than whether human freedom survives God's knowledge of future contingents, for it is at least possible for the latter question to attempt to rescue human freedom by appealing to God's eternal perspective to remove divine knowledge from the temporal order. That way seems closed to resolving the difficulty with prophecy, for we are here dealing with datable, historical utterances firmly embedded in the temporal order that nonetheless claim to 'announce [future] events by immutable truth.' If the promises of revelation necessarily eventuate, God as it were puts down stakes at one point in time on an event that has to happen later. God is not somehow outside time seeing events 'as they happen' in an eternal present. Rather, the word of God is inserted into time with reference to an event that from one significant frame of reference both has yet to be and must be a certain way.

13. Utrum generalis resurrectio, Streveler lines 494-498.

14. 83 Questions 14: "Si Christus fefellit, veritas non est."

15. Biblia sacra cum glossa interlineari, ordinaria . . . (Venice, 1588), 5:87r: "sic impossible est non fieri quod dixit." 
In sum, Holcot writes,

if the opposite of what was revealed is able to happen, God is able to deceive, lie, perjure, not to fulfill what he promises, and to be unfaithful, and so on; which seem to oppose good morals. On the other hand, if we say that the opposite of what has been revealed, or promised, or asserted, or sworn by God is not able to happen, it seems to impair the divine power, which in no way is diminished through revelation, or an oath, or a promise made to a creature. Moreover, it seems to impugn human liberty: because after a revelation is made of something falling under the free faculty of the will, it would now make it necessary if the opposite could not happen. ${ }^{16}$

It seems, therefore, that though we may want to affirm both the infallibility of divine prophecy (to preserve the veracity of God and Scripture) and the contingency of the events prophesied (to safeguard God's power and human freedom), we cannot hold to either without being impaled on the opposite horn of a dilemma. If we wish to maintain the necessity of revelation, we seem to surrender human freedom and God's power to do other than God promised. If we affirm the contingency of God's revelation, we challenge God's truthfulness and the veracity of Scripture. I turn now to Holcot's attempt to slip between these horns.

Holcot first seeks to determine whether God has an obligation to fulfill revelation. His answer to this will eventually be negative, but let us first examine the case he makes for such an obligation. In his quodlibet question, "Utrum generalis resurrectio necessario sit future," Holcot proposes an unpleasant dilemma for those who would affirm that revelation is only contingently true (that is, that God does not necessarily fulfill what God promises). Either for God not to do what God promises is unsuitable for God or it is not. If it is, then

16. Holcot Quodlibet 33 (Streveler lines 35-44): "[S]i dixerimus quod oppositum revelati potest contingere, quod Deus potest decipere, mentiri, periurare, non solvere quod promisit, et fieri infidelis, et huiusmodo, quae bonis moribus repugnare videntur. Ex alia parte, si dixerimus quod oppositum revelati, vel promissi, vel asserti seu iurati a Deo non potest evenire, videtur derogare divinae potentiae, quo in nullo minuitur propter revelationem, vel iuramentum, vel promissionem factam creaturae. Item, videtur derogare humanae libertati: quia facta revelatione de aliquo cadente sub libera facultate voluntatis, iam fieret necessarium si eius oppositum evenire non posset." This question, entitled "Utrum, facta revelatione alicuius futuri contingentis, ipsum maneat contingens post revelationem," will hereafter be cited by line number under the abbreviated title Utrum facta revelatione. 
there is something unsuitable in God, which is, according to Anselm, impossible. Therefore, it is impossible for God not to fulfill what God promises; and so God necessarily does what God promises. But if it is not unsuitable for God not to do what God promises, it seems to follow that it is not unsuitable for God either to be false (if God decides not to fulfill what God promises) or to be impotent (if God is unable to fulfill what God promises). Therefore, God's promises could be in vain, and prophecy could be in vain.

In both cases, we seem at first sight to be driven back to the conclusion that it is necessary for God to fulfill what God promises. If God necessarily fulfills what God promises, we are still faced with the problem of what this inability to be false entails for God's power. No imperfection is able to be in God. It would entail such an imperfection, says Holcot, if God were not able to assert something false knowingly. ${ }^{17}$ Certain creatures (like demons) deserve to be deceived by God. Furthermore, God ordered the sons of Israel to deceive the Egyptians. Similarly, Christ willed to be born of a virgin to deceive the devil. Rebecca and Jacob deceived Isaac; and Judith, Holofernes. So Holcot concludes that he sees no unsuitability in saying that God speaks falsely in the sense that God says God will do something and then God does not do it. ${ }^{18}$

Holcot explains that 'to deceive' is accepted among the doctors of the Church in different senses. It can mean nothing more, strictly speaking, than voluntarily to cause an error in someone so that he affirms as true what is in fact false. On the other hand, 'to deceive' can be understood more unsuitably as importing notions of wickedness, evil, and maliciousness. Holcot concludes that God can deceive by making someone believe a false thing, but not by being malicious. ${ }^{19}$

In addition to these scriptural examples of God's acts of deception, Holcot makes a more general point concerning God's independence from creation. He says that since no goodness can be added to God from any operation on a creature, God is not better when God acts justly and fulfills God's promises than when God does nothing at

17. Sentences, Streveler p. 97: "immo imperfectionis esset si non posset hoc intendere."

18. Sentences, Streveler pp. 97-98.

19. Utrum generalis resurrectio, Streveler lines 419-420: "Primo modo concedendum est quod Deus potest fallere: secundo modo non potest." 
all. To preserve the divine impassibility, Holcot needs to affirm that nothing pertaining to the essential goodness of God depends on a creature. To affirm otherwise is extremely absurd ("nimis absurdum"). God could even destroy every creature whatsoever without diminishing God's goodness. Consequently,

if God abrogated all his statutes and made it that they never were statutes and did nothing of his promises, he would not be less good than he was before the creation of the world, when there was nothing except himself. ${ }^{20}$

Indeed, God's causality causes everything in the universe to subsist. As Holcot says, God is not like the builder of a building who can walk away from his work without its crumbling to the ground. If God ever withdrew God's control from the world, it would be destroyed in the blink of an eye ("ictu oculi"). ${ }^{21}$ God's ability to annihilate the world and all its creatures is something to which Holcot frequently appeals. It seems to serve as the ultimate guarantee of the contingency of revelation, because it is the ultimate guarantee of the contingency of everything-including events that have been prophesied to occur in the future. So he writes,

God is able to annihilate all the angels and everything else.... But he is not any more necessitated to restore these things than he was necessitated in the beginning to produce them. But without souls and bodies a resurrection is not able to be made: therefore, it is not absolutely necessary that there be a resurrection. 22

If it is not necessary that there be a resurrection, it is not necessary that prophecies about one come true. The contingency of revelation follows naturally from the contingency of all things. But just as there is no inference from 'God killed the innocent' to 'God sins', so there is none from 'God does not do what he swore he would do' to 'God

20. Utrum generalis resurrectio, Streveler lines 292-294: "[S]i Deus omnia statuta sua abrogaret et faceret quo numquam fuissent statuta et nihil faceret de promissis, non minus bonus foret quam fuit ante mundi constitutionem, quando nihil fuit nisi ipse."

21. Utrum generalis resurrectio, Streveler lines 272-278.

22. Utrum generalis resurrectio, Streveler lines 224-228: "Deus potest adnihilare omnes angelos et omne aliud.... Sed non necessitatur ad ea reparandum plusquam necessitabatur in principio ad ea producendum. Sed sine animabus et corporibus non potest resurrectio fieri; igitur non est absolute necessarium quo fiat resurrectio." 
is perjurious'. Holcot reasons that the term 'perjurious' implies that God ought to do otherwise than God does out of respect for some law to which God is subjected and, consequently, upon which God's goodness depends. This would imply that God is obligated to serve this law or lose moral goodness. This is impossible according to Holcot. God's sovereign freedom grounds the contingency of revelation. In his quodlibets, Holcot adduces five proofs from Duns Scotus and eight from Thomas Aquinas to make the point that God acts freely and of God's own will. If the general resurrection were not freely and contingently done by God, Holcot argues, then God would be necessitated to do something outside of God's self. ${ }^{23}$ God's power knows no such constraints. Therefore, the consequent of the above conditional must be false. By modus tollens, the general resurrection is freely and contingently done by God.

Holcot goes on to explain that if everything were necessary after it had been revealed, it would follow that God is not able to reveal a proposition such as, 'Socrates will contingently sin tomorrow'. For this to be necessary would be to reveal that something presumably coming under the free faculty of Socrates' will (namely, the ability to sin or not) is not able not to happen. So if he will not sin contingently and he does sin, then he sins necessarily. He is thus not able to avoid his sin and so cannot be held accountable for his action. If so, thought Holcot, he would not sin at all. Consequently, it must be the case that 'Socrates will sin' remains contingent after its revelation. To assume otherwise leads to a contradiction.

Just asserting the contingency of revelation, however, does not solve all our problems. It may in fact create more. Consider divine immutability, for instance. If God is able not to fulfill God's revealed word, then it would seem that God is able to change; for God can decide not to keep a promise God had previously planned to keep. Holcot certainly doesn't want to surrender God's immutability. Then doesn't this point undo all previous attempts to secure the contingency of revelation and inevitably lead us back to the conclusion that God necessarily fulfills what God reveals?

No, because something is contingently true, according to Holcot, which is true but able never to have been true ("hoc est esse

23. Utrum generalis resurrectio, Streveler lines 220-223: "Deus necessitaretur ad agendum aliud extra se." 
contingenter verum, videlicit, esse verum et posse numquam fuisse verum"). ${ }^{24}$ If it turns out that there never is a resurrection, it is not as though God suddenly changed God's mind and, consequently, that the truth value of 'There will be a resurrection' changed from true to false. Rather, it was false from eternity. This does not entail that it was necessarily false. It was able to have been true from eternity, whence its contingency. If there is a resurrection, then the statement was true from eternity. So Holcot says that God knew that God would voluntarily and freely ("voluntarie et libere") produce the world, but God never began to know this. God knew this from eternity ("sed hoc numquam incepit scire, ergo ab eterno scivit se producturum mundum"25). Therefore, God's actions are not necessary and God's will is not mutable in the face of this contingency. Holcot relates with approval the following from Peter Lombard, Sentences 1.43.11:

"God," [the Lombard] began, "is able to do other than he does, and nevertheless, if he does otherwise, he would not be different. And he is able to will other than he wills; and nevertheless his will is able to be neither other, nor new, nor mutable in any way. For if he is able to will what he never willed, neither nevertheless newly nor by a new will, but only eternally is he able to will. For he is able to will what from eternity he was able to have willed." Therefore, it is plain according to the Teacher that this conditional is not valid: "He is able to will the opposite of that which he now wills; therefore his will is mutable," because he is able never to have willed that which he now wills, just as he is able never to have willed that Peter is predestined. ${ }^{26}$

What is even more significant from the perspective of a preacher, if revelation is contingent, Scripture can be false and with it the whole faith. All medieval Christian writers presupposed the veracity

24. Utrum generalis resurrectio, Streveler lines 388-389.

25. Sentences, Streveler p. 17.

26. Utrum generalis resurrectio, Streveler lines 657-666: “'Potest,' inquit, 'Deus aliud facere quam facit; et tamen, si aliud faceret, non alius ipse esset. Et potest aliud velle quam vult; et tamen eius voluntas nec alia, nec nova, nec mutabilis aliquo modo esse potest. Et si enim potest velle quod numquam voluit, nec tamen noviter nec nova voluntate, sed sempiterna tantum velle potest. Potest enim velle quod $a b$ aeterno potuit voluisse.' Igitur, patet secundum Magistrum quo ista consequentia non valet: 'potest velle oppositum illius quod nunc vult; igitur voluntas eius est mutabilis,' quia potest numquam voluisse illus quod modo vult, sicut potest numquam voluisse Petrum esse praedestinatum." 
of Scripture. If revelation could be false, however, everything was at stake. In one pithy remark in the Sentences-commentary, Holcot lays out the far-reaching implications.

And it is possible that those who believed in him [Christ] were mistaken, and the whole faith is false, and God spoke falsely to those whom he taught. ${ }^{27}$

On the face of it, this is an odd thing for one charged with winning converts to admit. It seems at the very least counterproductive. Furthermore, repeated emphasis of the radical contingency of all things is hardly consoling for prospective converts. Faith would then yield no less an uncertain destiny than the lack of it. What, then, was Holcot attempting to say here, and why is he saying it? Allow me to hazard a guess. Philosophy was a crucial tool for Holcot, a prolegomenon to his preaching. Philosophical concern about prophecy, contingencies, and the freedom of God shows the necessity-as philosophy cannot itself do-of faith. Though philosophy cannot fully plumb the depths of faith, its value lies precisely in recognizing its own limitations. This is a fundamentally Thomistic insight.

Holcot's emphasis on faith represents his theological response to the questions he raises in the quodlibets and Sentences-commentary about the status of revelation. One of the main arguments he had proposed against the contingency of revelation is this: If the resurrection of the dead is only contingently future, then all things would be dependent on the free will of God. Yet, according to Augustine in De civitate Dei 11.11-13, the principal function of beatitude is the security of future beatitude. But what is contingent is able not to be; and what is able not to be is in no way able to be demonstrated as existing with certitude ("nequaquam esse certa ratione colligi potest"). Therefore, the blessed could never possess the certainty-and, consequently, the security - of their own future beatitude. 28

Holcot responds to this argument by saying that the certitude God effects in the blessed can never completely guarantee that it is necessary that something (including their continued beatitude) will exist. After all, revelation is contingent. But the certitude proper

27. Sentences, Streveler p. 8: "Et possible est omnis qui crediderunt in eum fuisse deceptos, et totam fidem esse falsam, et Deum fefellise homines quos docuit."

28. Utrum generalis resurrectio, Streveler lines 120-122 and 215-219. 
to the blessed is one possessed by faith, which causes a belief so strong that it is as if ( $a c s i)$ what is believed to be is not able to be otherwise-even though it always is. I shall shortly return to consider in more detail this ac si. It is a phrase that recurs in Holcot's writings. For the moment it is enough to quote a passage from his quodlibet, "Utrum, facta revelatione alicuius futuri contingentis, ipsum maneat contingens post revelationem."

I say that the certitude that God causes in the blessed is not such that something will be so and impossible that it will not be so. Consider that Linus knows that: "Linus will always be blessed...." God is not able to cause such certitude because it is impossible that God is such or is in such a state that he is not able to destroy every creature; because he freely conserves every creature just as he freely produced each one in the beginning. But he causes in them such certitude that they will always be blessed, and they cling to it so strongly and with such great assent, as if it is not able to be otherwise. They know nonetheless that it is able to be otherwise: because otherwise they would not know the condition of the creature's being always dependent on God. ${ }^{29}$

Holcot affirms that even Christ knows that his beatitude could not be continued, otherwise even he would be deceived if he believed himself to be blessed of necessity ("alias enim foret decepta si sic crederet se beatam quod necessario foret beata"). Nonetheless, Christ does have the security that his beatitude will be freely continued. 30

Holcot distinguishes two types of knowledge. First, there is the sort of knowledge acquired at the conclusion of a demonstration or proof. In this sense, even Christ does not and cannot know that there will be a resurrection; because what is contingently able not to be cannot be grasped by the type of certain reason arising from a rational demonstration. Second, knowledge can be construed as true estimation or

29. Utrum facta revelatione, Streveler lines 66-75: "[D]ico certitudo quam Deus facit in beatis non est talis quod sic erit, et impossible est quin sic erit. Puta, quod Linus sciat istam: 'Linus semper erit beatus....'... talem certitudinem Deus non potest causare, quia impossible est quod Deus sit talis vel in tali statu in quo non posset destruere omnem creaturam, quia omnem creaturam acque libere conservat, sicut libere a principio produxit. Sed causat in eis talem certitudinem quod semper erunt beati, et illi adhaerent ita fortiter et tanto assensu, ac si aliter esse non posset. Sciunt tamen quod aliter esse potest, quia aliter lateret eos conditio creaturae semper dependentis a Deo."

30. Utrum generalis resurrectio, Streveler lines 709-715. 
suspicion ("Alio modo accipitur scientia pro aestimatione vera vel suspicione vera"). In this sense, Christ does have knowledge of the future resurrection. Christ has such faith in a future resurrection that it can be said to be called scientia ("igitur habet de hoc tantum fidem, dicendum quod 'scientia' accipitur ad propositum"). ${ }^{31}$ Still, this knowledge is able to be made erroneous if God so wills ("tamen potest fieri error, si Deus voluerit"). 32

How confident can the ordinary believer really be of the revealed promises of God? Holcot wants to say that God fulfills God's promises as if they would be fulfilled by necessity ${ }^{33}$ or as if they could not not be fulfilled ("ac si non posset non impleri" ${ }^{4}$ ). "Nevertheless," writes Holcot, "they will be fulfilled freely and contingently." So Holcot can now interpret Luke 24:44 to mean that all things about Christ must be fulfilled as if by necessity-and similarly for the other scriptural passages cited previously.

There are no assurances, then, save the assurances of faith. Faith is the key. In his commentaries on Wisdom and Ecclesiasticus, Holcot tells a story in which he sounds very much like Pascal. He speaks of a Dominican lay brother's efforts to convert a heretic, who persists in disbelieving the immortality of the soul. Eventually the brother points out to the heretic that in the absence of proof, it is better to 'play safe'; for he would lose nothing by believing if his beliefs were false and gain everything if they do prove true. The heretic was converted. 35

In his Wisdom-commentary, Holcot acknowledges the role of faith in assuring the believer that God's promise of eternal life is true. It is faith that provides the assurance that God does not speak falsely. Though God can deceive, believers need not worry that God does deceive. Holcot writes,

it is plain from divine truth that God deceives no one but promises eternal life if we would do good and eternal punishment if evil; therefore it is so.

31. Utrum generalis resurrectio, Streveler lines 616-617.

32. Utrum generalis resurrectio, Streveler lines 622-623.

33. Utrum generalis resurrectio, Streveler lines 543-544: "ac si necessario forent implenda." Compare line 550.

34. Sentences, Streveler p. 123.

35. Super libros Sapientiae 15, Super Ecclesiasticum 19, as cited in Smalley, "Robert Holcot," p. 85. 
And although it is perhaps not able to be proven by natural reason, as is sufficiently apparent because of the weakness of the rational powers that both saints and philosophers bring to this question; it is nonetheless very appropriate to believe this-just as there are many other true things we do not know how to prove. 36

Holcot's position, then, seems to be this. There are certain things that cannot be proven given their natures. These include the reality of future resurrection and beatitude. Not even Christ could prove these things, and not even God can cause certain belief in them. These things can always not be. What can not be (which includes all created reality) cannot be grasped by the type of certain reason produced by demonstration. Other things do seem to be susceptible of proof. These include the divine veracity and unwillingness to deceive. Christ's faith in these things approaches a kind of scientia, according to Holcot, though such knowledge forever eludes the natural capacity of saints and philosophers.

What is contingently promised cannot be demonstrated. No analysis of promises could uncover any necessity in their fulfillment. Rather, a promise becomes a promise through the character of the one doing the promising. Philosophy cannot validate the truthfulness of the claims of faith. Still, by its proper display of the radical contingency of all things, philosophy can show how specific future contingencies can be true only if certain promises are kept. Believing in and on those promises is faith.

Heiko Oberman has referred to the relation between faith and reason in Holcot's work as "the riddle of Holcot's place in . . . medieval history." 77 Part of the reason for this riddle must rest with the diversity of Holcot's literary corpus. Some of his writings are philosophically sophisticated. Others bespeak little or no concern with the technicalities

36. Super libros Sapientiae 15, from Oxford, Balliol College MS 27, fol. 26 ${ }^{\text {vb }}$, as quoted by Smalley, "Robert Holcot," p. 82: "[P]atet ex divina veritate, quia Deus nullum fallit, sed promisit nobis vitam eternam, si bene fecerimus, et penan eternam, si male; ergo ita fiet. Et licet non possit forsitan ratione naturali probari, sicut satis patet per debilitatem rationum, que ad hoc tam a sanctis quam a philosophis adducuntur, summe tamen convenit hoc credere, sicut multa alia sunt vera, que probare nescimus."

37. Heiko Oberman, The Harvest of Medieval Theology: Gabriel Biel and Late Medieval Nominalism (Cambridge, Mass.: Harvard University Press, 1967), p. 236. 
and intricacies of philosophical issues or the philosophical methods then current. Thus the moral and scriptural writings were intended primarily to train preachers. They are not the appropriate place for developing detailed philosophical argumentation. But if such differences in audience and purpose determine the balance of philosophical subtleties and pastoral exigencies in Holcot's work, it is crucial to note that these two are never completely separated. The Wisdomcommentary, for example, contains several abbreviated statements of certain positions expounded more meticulously in quodlibets or the Sentences-commentary. ${ }^{38}$ Hence we have to be careful not to think that we can neatly segregate Holcot's more speculative philosophical agenda from his more practical, theological one.

There is also a converse influence, a linkage in the other direction. There are among his 'philosophical' works traces of a pastoral program. Holcot's concerns for prophecy and the contingency of revelation in the quodlibets and Sentences-commentary become more prolegomena than sophismata, laying the groundwork for what preachers must preach and what the object of conversion must be: a reliance upon divine promises as veridical. So it is that the concern with divine promises in the philosophical work also undergirds Holcot's treatment of grace in the Wisdom-commentary. According to Holcot, the believer can be confident that God has established a particular order in which certain acts are regarded as meritorious. "With God compulsory necessity has no place, but an unfailing necessity is appropriate to God because of his promise, that is, his covenant, or established law."39 God has promised or covenanted to put God's rewards-and hence God's self-at the disposal of the free actions and initiative of God's creatures. Holcot adduces scriptural warrant for this:

"Behold I stand at the door and knock. If anyone hears my voice and opens the door, I will come in to him and eat with him" (Revelation 3:20). Therefore, when man disposes himself for grace by doing whatever he can [faciendo id quod in se est] and thus opens himself, God necessarily

38. Smalley points out that even these abbreviated statements could have had a tremendous impact given the extraordinary diffusion of Holcot's Wisdom commentary ("Robert Holcot," 85).

39. Super libros Sapientiae 12.145; quoted and translated in Oberman, Forerunners of the Reformation, p. 149. 
comes in to him.... According to God's established law the pilgrim who does whatever he can to dispose himself for grace always receives grace. 40

I want to suggest, therefore, that the 'philosophical' Holcot of the quodlibets and Sentences-commentary and the more 'theological' Holcot of the Wisdom-commentary and pastorally oriented moral writings are quite complementary. They are so complementary that an attempt to focus on one apart from the other, or to try to separate philosophical from theological agendas, results in an incomplete picture of Holcot's enterprise. In the next part of this essay, I shall consider another theological topic that particularly concerned Holcot but which, at the same time, seems to depend rather heavily on the issues already articulated relating to prophecy and the contingency of revelation.

\section{THE MERIT OF FAITH}

The same divine freedom that establishes the contingency of revelation in one sense grounds it in another. Unlike Ockham, for whom God's potentia absoluta seemed not to represent a real power in God but an initial realm of possibility from which God chose the existing order, Holcot seems to have thought that God even now does occasionally act by absolute power to intervene in the established

40. Oberman, Forerunners of the Reformation, pp. 148-149. The expression "facere quod in se est" (literally, "to do what is in one") was commonly used to describe men and women's natural powers unaided by grace. For more on this aspect of Holcot's thought, see Heiko Oberman, "Facientibus Quod in se est Deus non Denegat Gratiam: Robert Holcot O.P. and the Beginnings of Luther's Theology," in The Reformation in Medieval Perspective, ed. Steven E. Ozment (Chicago: Quadrangle Books, 1971), pp. 119-141. For the sense of the phrase in medieval theology more generally, see Paul Vignaux, "On Luther and Ockham," in Reformation in Medieval Perspective, ed. Ozment, pp. 107-118; Bengt Hägglund, "The Background of Luther's Doctrine of Justification in Late Medieval Theology," Lutheran World 8 (1961): 24-46, at p. 40; Francis Oakley, Omnipotence, Covenant and Order (Ithaca: Cornell University Press, 1984), p. 62; Heiko Oberman, "The Shape of Late Medieval Thought," in The Pursuit of Holiness, ed. Oberman and Charles Trinkaus (Leiden: E. J. Brill, 1973), p. 15; Oberman, Forerunners of the Reformation, pp. 129-131; and Oberman, The Harvest of Medieval Theology, throughout. 
order. ${ }^{41}$ If Ockham and other contemporaries of Holcot distinguished conceptually between God's absolute and ordained powers, they did not think that God ever acts de potentia absoluta. Holcot disagreed. With his reliance on God's promises to create a particular kind of order, he needed to safeguard God's freedom and to protect God from any necessitating circumstances, including God's own prior promises, by invoking the real possibility of an exercise of absolute power. For Holcot, one of the primary consequences of God's freedom is God's ability through God's potentia absoluta to dispense with the order of grace and supernatural virtues established and sustained by God's potentia ordinata, which has chosen and maintained the present plan of salvation, and to accept the natural, unaided acts of people as meritorious for eternal life. Grace and the supernatural virtues are not needed under some exercises of God's absolute power to confer their goal, eternal life. Holcot writes that "God can accept all natural acts of any person for eternal life" ("Deus potest acceptare ad vitam eternam omnes actus naturales alicuius hominis") and that God can accept a natural act as meritorious for salvation ("actus naturalis sit meritorius si Deo placet"). ${ }^{42}$ Human beings can in some way gain grace through their own power, if only incompletely ("et sic aliquo modo habemus gratiam in nostra potestate: videlicet dispositive et incomplete: non tamen perfecte et effective"). .43

Actually, Holcot's views on merit contain some mixing of God's absolute and ordained powers. People can merit from God's potentia ordinata by obeying God's decrees, or God can accept their natural

41. Ockham discusses the distinction between potentia absoluta and potentia ordinata in his Quodlibet 61 and Summa logicae 3(4).6. For an excellent overview and anaylsis of these categories, see William Courtenay, "The Dialectic of Omnipotence in the High and Late Middle Ages," in Divine Omniscience and Omnipotence in Medieval Philosophy, ed. Tamar Rudavsky (Dordrecht: D. Reidel Publishing Company, 1985), pp. 243-270. I have also benefitted greatly from Paul Streveler's unpublished paper, "God's Absolute and Ordained Power in the Thought of Robert Holcot." Streveler writes (p. 7), "Holcot explicitly denies the presupposition that whatever God does $\mathrm{He}$ does by His ordained power." Another unpublished paper by Streveler, "Robert Holcot on Future Contingencies and Divine Omniscience," has also been very helpful.

42. Sentences 1.4.3H; quoted in Gordon Leff, Bradwardine and the Pelagians (Cambridge: Cambridge University Press, 1957), p. 217, note 2.

43. Sentences 1.4.3K; quoted in Leff, Bradwardine, p. 218, note 4. 
actions by potentia absoluta. ${ }^{44}$ Nonetheless, this ability of God to respond as God sees fit to the natural actions of people-God can eternally damn someone existing in grace and give eternal life to a mortal sinner 45 -has the consequence that someone can gain eternal beatitude without true belief or, indeed, any belief at all. Hence the earlier problems that false belief caused for the contingency of revelation lose their force for Holcot. Merit is not contingent upon true or false belief but rather is grounded in following the will of God.

for man by willing to believe a particular proposition that he is commanded to believe-when it is false-is able to gain merit: nor does it pertain to the merit of faith whether it is true or false.... That God is able to command someone to believe some false thing is not to be doubted. 46

Again, to the case cited earlier of the Sadducee who was 'unjustly' damned for believing what turned out to be true, Holcot responds, "I concede that such a person in the case posited has been justly damned not because he believed what is false but because he did not believe as God commanded he believe." 47

The issue of merit through false faith is closely related to the subject of merit through what Holcot called 'invincible ignorance' ("ignorantia invincibilis"); for both depend on the power and freedom of God to confer eternal life upon whomsoever God wills. ${ }^{48}$ References to these topics appear in Holcot's quodlibet questions, Sentences-commentary,

44. See Leff, Bradwardine, p. 220.

45. Sentences 1.4.3H; quoted in Leff, Bradwardine, p. 217, n. 2.

46. Sentences $1.1 \mathrm{R}$, quoted in Leff, Bardwardine, p. 221, n. 3: "[H]omo enim volendo credere certam propositionem quo precipitur esse credenda: et est falsa: potest mereri: nec pertinet ad meritum fidei utrum sit vera an falsa. . . Posse autem Deum precipere aliquem falsum credi non est dubium."

47. Utrum generalis resurrectio, Streveler lines 441-443: "[C]oncedo quod talis iuste est dampnatus, non quia credidit falsum in illo casu posito, sed quia non crededit sicut Deus praecepit quod crederet."

48. Holcot was certainly not alone in his interest in this question. Albert Lang describes a pervading consciousness of an obligation for tolerance which in the first half of the fourteenth century led to a great deal of scholarly speculation over the question of implicit faith. See his Die Entfaltung des apologetischen Problems in der Scholastik des Mittelalters (Freiburg i. Br.: Herder, 1962), pp. 193-194, n. 60, and pp. 88-91. 
and Wisdom-commentary. For example, Holcot writes in Quodlibet 3, "In fact, nevertheless, many receive merit in false faith and are excused through invincible ignorance together with the good will of believing well." 49 In his Sentences-commentary, he presents a more sustained case.

if it suffices for an old lady to believe just as her prelate preaches to her, and the prelate is a heretic, she, therefore, merits by believing heresy. Let it be, therefore, that the old lady is killed for a heretical article that she believes to be Catholic: either she is a martyr or not. If yes, an argument against-she is not a witness of the truth; nor does she die for the faith; nor for justice. Therefore, nothing makes her a martyr. If not, an argument against... she intends to defend the faith and is invincibly ignorant. Therefore, her intention is pure. Therefore, someone is able to merit in false faith.... And thus it would be possible that someone is killed as a martyr-this person being worthy of the prize of the martyr-and nonetheless he believed the opposite of the articles of faith and merited precisely because he believed the opposite of the articles of faith..$^{50}$

According to Beumer, Holcot's ideas on invincible ignorance were quite original and significant for the discussion that followed

49. Utrum generalis resurrectio, Streveler lines 438-440: "De facto tamen multi merentur in fide false et excusantur per ignorantiam invincibilem concomitantem bonam voluntatem bene credendi." Thomas Aquinas speaks about invincible ignorance, though not in the context of merit. See his Summa theologiae 1-2.76.2-3 and 1-2.88.6.ad 2. In an unpublished paper on "The Reach of Grace Outside of Church, Faith and Baptism in Thomas Aquinas's Theology," Thomas O'Meara writes, "The issue, however, of salvation for those who had not heard of the Gospel did not attract as much interest from the theologians of the thirteenth century as we might expect. We do not find a disputation by Thomas, or a question or an article in the Summae theologiae which consider directly other contemporary religious groups. Nevertheless, there are about a dozen articles in the ST which touch on our topic obliquely ..." (p. 3).

50. Sentences 1.1.6 argum. princip. A; quoted in Beumer, Entfaltung des apologetischen Problems, p. 515: "[S]i sufficit vetule credere, sicut prelatus suus ei predicat, et sit ita quod prelatus sit hereticus, ista ergo meretur credendo heresim. Ponatur ergo, quod illa vetula interficiatur pro articulo heretico quem putat esse catholicum: aut est martyr vel non. Si sic, contra, not est testis veritatis nec moritur pro fide; nec pro iustitia; ergo caret causa. Si non: contra . . . intendit defendere fidem et est ignorantia invincibilis. Ergo intentio est integra; ergo aliquis mereri potest in fide falsa....Et sic esset possibilis quod aliquis efficeretur martyr, hoc est dignus premio martyrum, et tamen crederet oppositum articuli et mereretur precise quia credidit oppositum articuli fidei." 
him. ${ }^{51}$ Here, Holcot describes the case of those who want to be saved, but who do not know what to believe for their salvation.

Some, worried about obtaining salvation, want and desire to know what are the means necessary for salvation. And since they understand that to believe is necessary for salvation, they then desire to believe and want to believe and have a prompt spirit for doing whatever is necessary for salvation and, whosoever were such in whatsoever way, I believe that they are saved in some way through divine grace. 52

God's freedom and potentia absoluta enable God to accept natural, unaided human actions as meritorious for salvation. Holcot had something like a personal stake in these issues, as his interest in them joined with his strong classicizing tendencies, his proto-Humanist studies and his interest in pagan antiquity that appear in clearest focus in his scriptural and moral writings. ${ }^{53} \mathrm{He}$ read widely in classical literary works and became an assistant of the great book collector and book lover, Bishop Richard de Bury. Holcot even corresponded with Petrarch. How might these interests have carried over to his theology? If one could be saved in false faith, one could certainly be saved just as well without any faith at all. Holcot concedes as much: people are able to merit without faith if it so pleases God ("potest dici quod sine fide posset homo mereri si deo placeret"). 54 This opened heaven up for many whom Holcot read.

Holcot claims that even the pagan philosophers had knowledge and belief in God for the following four reasons: First, they never denied that God exists. Second, many of them believed in only one God. Third, the philosophers accepted the fact that many since the origin of

51. Beumer, Entfaltung des apologetischen Problems, pp. 525-526.

52. Sentences 1.1.6K, quoted in Beumer, Entfaltung des apologetischen Problems, p. 518: "[A]liqui solliciti de salute consequenda volunt et desiderant scire que sunt media et ad salutem necessaria: et cum intellexerint, quod credere sit necessarium ad salutem, tunc desiderant credere et volunt credere et habent animum promptum ad faciendum quidquid est necessarium ad salutem et, quicumque fuerent tales in quacumque secta, credo eos per divinam gratiam aliquo modo salvados."

53. See Smalley, "Robert Holcot," especially pp. 5, 7, 65, 71. According to Smalley, Holcot belonged to a group of fourteenth-century commentators on Scripture who "hoped that their teaching and preaching would make more impression if they presented it gracefully" (p. 5).

54. Utrum theologia sit scientia (Muckle 127): "potest dici quod sine fide posset homo mereri si deo placeret." 
the world worshipped God (like Adam, Noah, and others). Finally, as Holcot writes in the third book of his Sentences-commentary, "I say that of these philosophers or wise men of the world, certain of them performed in a divine cult in compliance with some rites and professions and were saved; just as is established of Job, Socrates, Plato, Aristotle, and is able to be presumed of most bands of Stoics." 55 Holcot thus completes Thomas's 'baptizing Aristotle' by almost quite literally baptizing him.

What is especially interesting about this topic of merit apart from the true faith, I think, is how it draws together several different motives in Holcot's writings. Is it possible that the issues about God's power and the contingency of revelation were actually meant by Holcot to clear some of the philosophical ground for the consideration of this very practical and pastoral question about merit without faith due to invincible ignorance? Such merit clearly seems to underscore the contingency of revelation. Faith, Holcot recalls in De imputabilitate peccati, is from hearing ("fides sit ex auditu," the classic text from Hebrews). Those who grow up in a place where they are unable to hear the articles of faith are in no way blameworthy ("ignorantia illorum non foret imputabilis ad culpam"). Holcot concludes that they can be saved regardless of their lack of explicit knowledge of the articles of faith ("dico quod salvaretur non obstante ignorantia fidei"). ${ }^{56}$ Hearing the Word is therefore not necessary for salvation. In fact, hearing the Word is a strikingly contingent event. It depends on when one was born and the community in which one matured. Holcot is very much aware of such contingencies and especially of the role of the community in fostering faith. He writes,

I believe, however, that in modern times many Christians believe because having been brought up among believers, they were accustomed from

55. Sentences 3.1.5RR-SS, as quoted in Beumer, Entfaltung des apologetischen Problems, p. 519: "Quarto, dico, quod de istis philosophis aut mundi sapientibus quidam in divino cultu secundum aliquos ritus et protestationes prestiterunt et salvati sunt: sicut constat de Job, de Socrate, Platone, Aristotele, et plurima turba stoicorum presumi potest." Compare Oberman in Harvest of Medieval Theology, p. 245: "Holcot takes I Tim. 2:4 quite seriously: "God desires all men to be saved and to come to the knowledge of the Truth.'"

56. De imputabilitate peccati 4BB; quoted in Beumer, Entfaltung des apologetischen Problems, pp. 521-522. 
childhood to hear the articles that they ought to believe in. For they began from infancy the honoring of God and fear of him; because they saw that their progenitors and other true and honest men believed such things. 57

Once Holcot dispensed with the requirement of proper belief for salvation for particular philosophical and theological reasons, the way to salvation was opened both for those living in Holcot's own time who had never heard the Christian message proclaimed and for any number of great figures from pagan antiquity who were now able to join the company of the elect.

Obviously, as a Dominican, a member of the Order of Preachers, Holcot was concerned with those in his own day who had not heard the Gospel message. The issue would undoubtedly have been especially important for someone charged with the care of souls. But as a preacher with classicizing tendencies and humanist sensibilities, he must have been equally concerned with his teachers from classical antiquity. As a philosopher and a Christian, he was confident that God's power governed both groups and that God's mercy (an abundant theme in the Wisdom-commentary $)^{58}$ came to them equally.

In these ways, Holcot displayed a keen sensitivity to the contingencies and historical limits of evangelization, a fact reinforced as more and more was learned about communities that had yet to hear the Gospel. More generally, Holcot's earlier concerns about the contingency of revelation through prophecy may thus be said to complement

57. Sentences 1.1.6K, as quoted in Beumer, Entfaltung des apologetischen Problems, p. 518: "Puto autem quod modernis temporibus multi christiani idea credunt, quia inter credentes educati articulos credendos a pueritia consueverunt audire, nominationem etiam Dei et eius timorem ab infantia conceperunt, quia suos progenitores et alios veraces et honestos talia credere vident."

58. One thing that certainly does appear in his moral and scriptural writings (whether as a consequence of his relaxation of philosophcial rigor or not, I do not know) is a more personal conception of God than I have observed in the quodlibets or Sentences-commentary. Again and again Holcot returns to the theme of God's mercy. Thirteen of his Moralitates, a series of moralized exampla for the use of preachers, deal with God's mercy and love for sinners. And in his Wisdom commentary, Holcot says such things as, "it is declared how God rules all things: especially human nature by mixing his power with his mercy" (Super libros Sapientiae lect. 142A); or that God governs humans through mercy (lect. 144A), or that "God made all things through his wisdom; he conserves all things through his goodness" (lect. 144A). 
these present concerns about the contingency of revelation through evangelization. Both reveal a God of sovereign freedom. In both, though in different ways, Holcot's philosophical sensibilities connect with his pastoral sensitivities in a manner which is, as far as I can tell, unique among his contemporaries.

\author{
St. Mary's College \\ Notre Dame, Indiana
}

